\title{
A COMPARATIVE STUDY OF CONJUNCTIVAL AUTOGRAFT AND BARE SCLERA TECHNIQUES IN THE TREATMENT OF PTERYGIUM
}

\author{
M. MUHAMMAD IDRIS ${ }^{1}$, N. DIVYA ${ }^{2 *}$, V. PANIMALAR A. VEERAMANI ${ }^{3}$, BINDU BHASKARAN ${ }^{4}$ \\ 1,2,3,4 Department of Ophthalmology, Saveetha Medical College and Hospital, Chennai, Tamil Nadu, India \\ Email: divya.q7@gmail.com
}

Received: 10 Jul 2020, Revised and Accepted: 08 Sep 2020

\begin{abstract}
Objective: Pterygium is a fibrovascular growth encroaching from the conjunctiva into the cornea. This study deals with the comparison of conjunctival autograft and bare sclera technique as treatment options for pterygium.

Methods: This study was done in the ophthalmology department of Saveetha Medical College, Thandalam, Chennai. A total of 100 patients were diagnosed of pterygium was taken for the study, out of which 60 patients were operated on with conjunctival autograft and 40 patients were operated with bare sclera technique. Patients with hypertension, diabetes mellitus were excluded. Post-operative complications and recurrence
\end{abstract} were noted. All the patients were between the age group of 20-65 $\mathrm{y}$.

Results: The mean age of patients operated with conjunctival autograft was 43.6, whereas in bare sclera technique was 46.625 . The maximum age was 63 and the minimum age was 23 in conjunctival autograft whereas in bare sclera technique, the maximum age was 64 and the minimum age was 22. The recurrence rate of pterygium in conjunctival autograft was 1 and the recurrence rate of pterygium in bare sclera technique was 4 .

Conclusion: The present study revealed that conjunctival autograft was a better treatment option compared to the bare sclera technique for excision of pterygium

Keywords: Bare sclera technique, Conjunctival autograft technique, Gender, Occupation, Pterygium, Recurrence rate, Treatment options

(c) 2020 The Authors. Published by Innovare Academic Sciences Pvt Ltd. This is an open access article under the CC BY license (http://creativecommons.org/licenses/by/4.0/) DOI: http://dx.doi.org/10.22159/ijcpr.2020v12i6.40302. Journal homepage: https://innovareacademics.in/journals/index.php/ijcpr

\section{INTRODUCTION}

Pterygium is defined as the non-cancerous, wing-shaped of the conjunctiva encroaching upon the cornea from either side within the interpalpebral fissure [1,2]. Pterygium is derived from the Greek word Pterygos=little wing. Susrutha describes pterygium way back in $1000 \mathrm{bc}$. Etiology of pterygium is not definitely known. This is common with exposure to high ultra-violet radiation and some other environmental pathogenesis like wind, dust, smoke, chemicals, heat and pollens play an important role. The risk of pterygium is common with an occupation like salt workers, policemen, postman and daily wage workers due to high exposure to heat and UV radiation [3]. Asia and other countries of the world located between $37^{\circ}$ north and $37^{\circ}$ south is known as extends of pterygium belt, as pterygium is common in the equatorial belt [4]. The incidence of pterygium is more common in males than in females [5].

Morphology of pterygium is of four parts: Head (Apical part present on the sclera), Neck (constricted part present in the limbal area), Body (scleral part extending between the limbus and the canthus) and the Cap (semilunar whitish infiltrate present just in front of the head) [2].

Surgical techniques for the excision of pterygium, which are commonly used are conjunctival autograft, bare sclera, amniotic membrane graft, but a definitive technique is not known since all have a considerable amount of complication and recurrence. On the adjunctive medical therapies included in the management of pterygium are lamellar keratoplasty, mucous membrane graft, chemotherapy by Thiopeta, beta irradiation and antimetabolite therapies like 5-flurouracil, mitomycin c but all these adjunctive therapies have their own share of side effects [6].

The aim of this study is to compare the conjunctiva autograft and bare sclera techniques as treatment options for pterygium excision.

\section{METHODS AND MATERIALS}

The study was conducted at Saveetha medical college and Hospital, Chennai, Tamilnadu in which a total of 100 eyes diagnosed with pterygium was included. Out of which 60 patients (39 males and 21 females) were operated on with conjunctival autograft and 40 patients (24 males and 16 females) were operated on with bare sclera technique. All patients were of age group between 20-65 y old in this study. Patients with hypertension, diabetes mellitus, cataract and dry eye were excluded from the study. All the patients were told to fill up the name, age and sign in the standard consent form after explaining the surgery and the study.

\section{Preoperative procedures}

Routine investigations such as blood pressure complete blood count, blood sugar test and detailed slit lamp examination were done before the operation.

\section{Operative procedure}

All the patients were operated on under local anesthesia after cleaning the eye thoroughly with $7.5 \%$ of betadine solution i.e. povidone-iodine solution. A peribulbar block was given with local anesthesia of $2 \%$ lidocaine and $0.1 \%$ bupivacaine. In bare sclera technique, the pterygium is removed by holding the body of pterygium with toothed forceps and separated along with the tenon's capsule with the help of $\mathrm{D}$ blade. Care is taken so that not to damage the medial rectus muscle. The bare sclera is left to heal. In the conjunctival autograft technique, the bare sclera is covered with a graft taken from the superior part of the sclera based on the measurements. The autograft is then sutured.

\section{Post-operative procedures}

Bandage is opened after $12 \mathrm{~h}$ of surgery. Antibiotic and prednisolone eye drops were given for 6 times a day. Tab Diclofenac was given twice a day for $3 \mathrm{~d}$. Post-operative follow up is done to see any recurrence or complications are present and is recorded. Datas are recorded in tabulated form.

\section{RESULTS}

The present study was conducted in 100 patients diagnosed with pterygium, of which 60 patients (39 males and 21 females) were operated on with conjunctival autograft and 40 patients (24males and 
16females) were operated by bare sclera technique. All the patients included in this study were between 20-65 y old. The mean age in the conjunctival autograft technique is 43.6; the maximum age was 63 , the minimum age was 23 . In bare sclera technique, the mean age was 46.625 , the maximum age was 64 , the minimum age was 22 . The recurrence rate in conjunctival autograft technique was 1 and in bare sclera technique was 4 . Out of the 100 patients, 71 of the patients were having outdoor occupation and 29 were having indoor work.

\section{DISCUSSION}

Pterygium is a fibrovascular wing-shaped encroachment from the conjunctiva to the cornea. It's a common disease in India as it lies in the equatorial belt. It is most common due to UV exposure and dust [7]. Genetic factors are also involved in causing pterygium. The excision of pterygium with bare sclera technique is common but has a more recurrence rate than the conjunctival autograft technique.

Table 1: Distribution of pterygium based on age and gender

\begin{tabular}{|c|c|c|c|c|}
\hline \multirow[t]{2}{*}{ Age (years) } & \multicolumn{2}{|c|}{ Conjunctival autograft technique } & \multicolumn{2}{|c|}{ Bare sclera technique } \\
\hline & Male & Female & Male & Female \\
\hline $20-30$ & 2 & 1 & 1 & 0 \\
\hline $31-40$ & 12 & 7 & 5 & 2 \\
\hline $41-50$ & 15 & 8 & 10 & 8 \\
\hline $51-60$ & 8 & 4 & 7 & 4 \\
\hline $61-65$ & 2 & 1 & 1 & 2 \\
\hline \multirow[t]{2}{*}{ Total } & 39 & 21 & 24 & 16 \\
\hline & \multicolumn{2}{|c|}{ Conjunctival autograft } & \multicolumn{2}{|c|}{ Bare sclera } \\
\hline Maximum age & \multicolumn{2}{|c|}{63} & \multicolumn{2}{|c|}{64} \\
\hline Minimum age & \multicolumn{2}{|c|}{23} & \multicolumn{2}{|c|}{22} \\
\hline Mean age & \multicolumn{2}{|c|}{43.6} & \multicolumn{2}{|c|}{46.625} \\
\hline
\end{tabular}

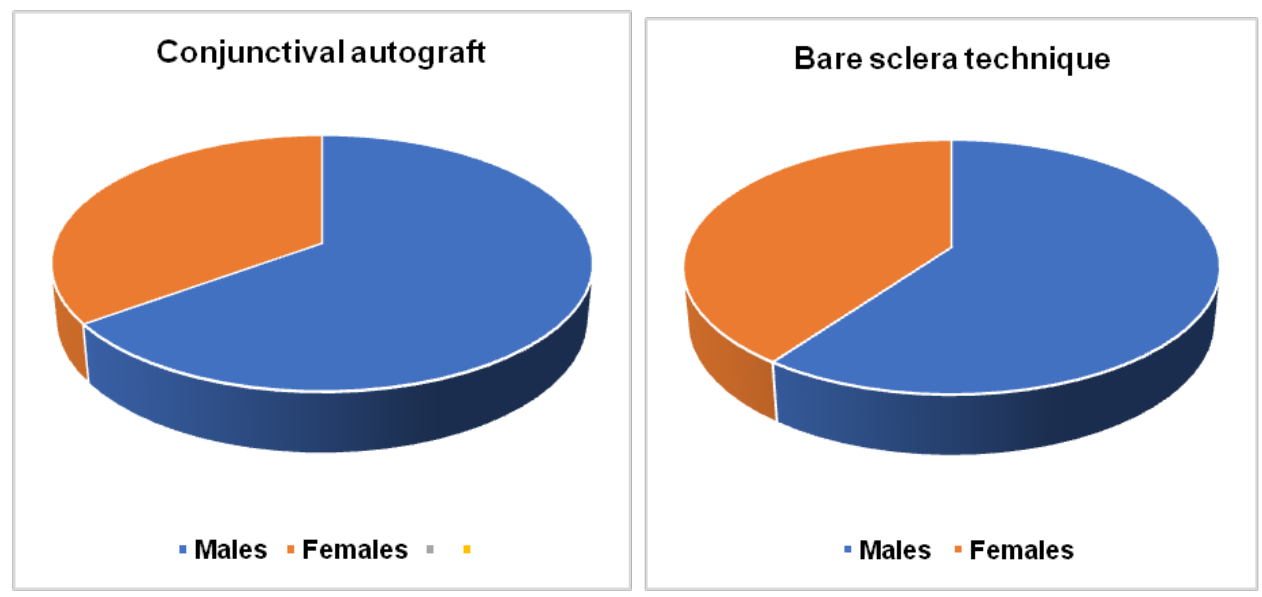

Fig. 1: Conjunctival autograft and bare sclera

Table 2: Classification based on occupation

\begin{tabular}{llll}
\hline Technique & Number of patients & Occupation & Indoor \\
\cline { 3 - 4 } & & Outdoor & 17 \\
Conjunctival autograft & 60 & 28 & 12 \\
Bare sclera & 40 & 71 & 29 \\
Total & 100 & 29 & \\
\hline
\end{tabular}

The study reveals the comparison between conjunctival autograft and bare sclera technique as treatment options for pterygium and its recurrence rates. The study was done on 100 patients diagnosed with pterygium, of which 60 (39 males and 21 females) patients were operated on with conjunctival autograft and 40 (24 males and 16 females) patients were operated with bare sclera technique. The mean age in conjunctival autograft was 43.6, maximum age was 63 and the minimum age of 23 , whereas in bare sclera technique the mean age was 46.625 , the maximum age was 64 and minimum age was 22 . The incidence of pterygium was more in males compared to females.

In this study, the recurrence rate of pterygium in patients operated with conjunctival autograft was 1 and whereas in patients operated with bare sclera technique was 4 which correlates with the studies of Ahmed 2012 [8], Kompali 2016 [9], Jain A [10] and Alapey [11].

In this study, 71 patients were having an outdoor occupation and 29 patients were having an indoor occupation which correlates with other studies.

\section{CONCLUSION}

This study stated that conjunctival autograft was a better treatment options compared to bare sclera technique as it has lesser recurrence rate and indicated that the incidence of pterygium is more in males compared to females.

\section{FUNDING}

Nil

\section{AUTHORS CONTRIBUTIONS}

All the authors have contributed equally.

\section{CONFLICT OF INTERESTS}

Declared none

\section{REFERENCES}

1. Rosenthal JW. Chronology of pterygium therapy. Am J Ophthalmol 1953;36:1601-16. 
2. Khurana AK, Khurana B. Comprehensive ophthalmology: with supplementary book-review of ophthalmology. JP Medical Ltd; 2015. p. 89-91.

3. Al-Bdour MD, Al-Latayfeh MTM. Risk factors for pterygium in an adult Jordanian population. Acta Ophthalmologica Scandinavica 2004:82:64-7.

4. Shiroma H, Higa A, Sawaguchi S, Iwase A, Tomidokoro A Amano S, et al. Prevalence and risk factors of pterygium in a southwestern island of Japan: the kumejima study. Am J Ophthalmol 2009;148:766-71.

5. Bradley PG, William MT. Pterygium. The Cornea. $2^{\text {nd }}$ ed. Butterworth-Hienmann Boston; 1998. p. 497-521.

6. Khan N, Ahmad M, Baseer A, Kundi NK. To compare the recurrence rate of pterygium excision with bare-sclera, free conjunctival auto graft and amniotic membrane grafts. Pakistan Journal of Ophthalmology; 2010. p. 26.
7. Saw SM, Tan D. Pterygium: prevalence, demography and risk factors. Ophthalmic Epidemiol 1999;6:219-28.

8. Ahmed IFTIKHAR, Ahmed MUNIR, Ahmed WAQAR Comparison of limbal conjunctival autograft with conventional bare sclera technique in the prevention of recurrence of pterygium. Pak J Med Health Sci 2012;6:629-31.

9. Kompalli JNSC. Pterygium excission bare sclera technique vs autologous conjunctival autograft-a prospective study. IOSR J Dental Med Sci 2016;15:20-3.

10. Jain A. A comparison between conjunctival autograft with bare sclera technique in pterygium excision and its recurrence. Int J Sci Stud 2018;6:123-6.

11. Alpay A, Ugurbaş SH, Erdogan B. Comparing techniques for pterygium surgery. Clin Ophthalmol (Auckland, NZ) $2009 ; 3: 69$. 